\title{
Haemoglobin Levels in Cardiff Children of Nursery School Age
}

\author{
D. M. D. EVANS, J. LEWIS, and ENID CURRAN \\ From St. David's Department of Pathology, the University Hospital of Wales (Cardiff) H.M.C., and Cardiff Public \\ Health Department, Cardiff
}

\begin{abstract}
Evans, D. M. D., Lewis, J., and Curran, E. (1972). Archives of Disease in Childhood, 47, 772. Haemoglobin levels in Cardiff children of nursery school age. A study of 1074 apparently healthy children aged 2 to 5 years revealed a wide range of haemoglobin, extending from $6.8 \mathrm{~g} / 100 \mathrm{ml}$ to $15.6 \mathrm{~g} / 100 \mathrm{ml}$. The mean $\mathrm{Hb}$ was $12.3 \mathrm{~g} / 100 \mathrm{ml}$, with only minor variations for age, sex, and season. A significant increase in the $\mathrm{Hb}$ followed iron administration if the initial $\mathrm{Hb}$ was less than $10.5 \mathrm{~g} / 100 \mathrm{ml}$, but there was no rise in the mean value if the initial level exceeded $12.5 \mathrm{~g} / 100 \mathrm{ml}$. Taking $10.5 \mathrm{~g} / 100 \mathrm{ml}$ as the level below which anaemia is deemed to exist, $5 \cdot 2 \%$ of the total study population were anaemic, compared with $0.3 \%$ in private nurseries, $3.7 \%$ in local authority nurseries, and $15 \%$ of infants on admission into the care of residential nurseries.
\end{abstract}

The initial purpose of the present study was to determine whether there was a significant incidence of anaemia in otherwise healthy Cardiff children of nursery school age. We then examined the possibility of variation with sex, age, and season, before evaluating the effect of iron administration on $\mathrm{Hb}$ level and red cell appearance. Finally the relation of social class to $\mathrm{Hb}$ level was investigated.

\section{Materials and Methods}

Population studied. A total of 1074 children between 2 and 5 years of age at the first test were included. This constituted approximately 1 in 15 of the total population in this age group, Cardiff's present birth rate being approximately 5000 per annum. This group comprised 618 children in the local authority nurseries, 323 children in private nurseries, and 133 children on admission into residential nurseries of the Children's Department.

Methods of examination. At the nurseries capillary blood was collected by fingerprick for $\mathrm{Hb}$ (cyanmetha:moglobin) estimation and two blood films were prepared, stained by the Jenner-Giemsa method. All the films were assessed by the same observer (J.L.). Blood collection was greatly facilitated by the absence of parents.

Repeat tests. The initial tests were undertaken in the winter months (November to April). To assess

Received 28 March 1972. possible seasonal variation, tests were repeated immediately after the summer holiday.

Response to iron administration. A sample of 164 children was selected, constituting about $25 \%$ of the children tested in the local authority day nurseries and including many with a $\mathrm{Hb}$ level of below $12.5 \mathrm{~g} /$ $100 \mathrm{ml}$. Each child received one tablet of 'Ferrodic' (Allen and Hanbury) daily for 6 weeks, each tablet containing $50 \mathrm{mg}$ iron as ferrous carbonate and ascorbic acid B.P. $12.5 \mathrm{mg}$. Approximately 30 tablets were given to each child.

\section{Results}

\section{Haemoglobinometry.}

Overall initial examination. The initial examinations revealed a wide range of $\mathrm{Hb}$ levels in the 1074 children (Fig. 1). All except 2 cases (i.e. $99.88 \%$ of the total number) had a $\mathrm{Hb}$ level between $8 \cdot 4 \mathrm{~g} / 100 \mathrm{ml}$ and $15 \cdot 2 \mathrm{~g} / 100 \mathrm{ml}$, the 2 exceptions being $6 \cdot 8 \mathrm{~g} / 100 \mathrm{ml}$ and $15 \cdot 6 \mathrm{~g} / 100 \mathrm{ml}$. The mean $\mathrm{Hb}$ concentration was $12 \cdot 3 \mathrm{~g} / 100 \mathrm{ml}$ (SD 1.1).

Variation with sex and age. The mean $\mathrm{Hb}$ concentration for the age range of 2 to 5 years was $12.4 \mathrm{~g} / 100 \mathrm{ml}(\mathrm{SD} 1 \cdot 1)$ in girls and $12 \cdot 2$ $\mathrm{g} / 100 \mathrm{ml}$ (SD 1.0 ) in boys. Similar differences between the sexes were observed for each year's class.

For both sexes considered together the mean $\mathrm{Hb}$ level was $12.0 \mathrm{~g} / 100 \mathrm{ml}(\mathrm{SD} 1 \cdot 1)$ in the $3 \mathrm{rd}$ 


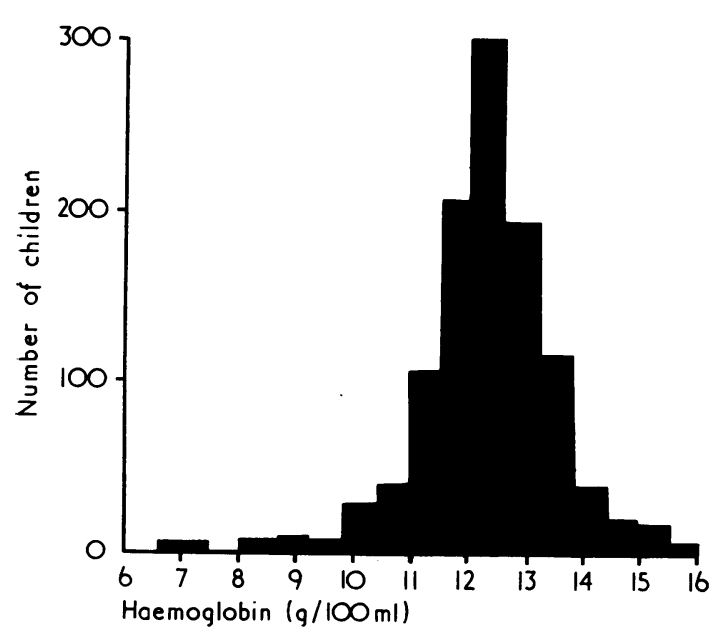

FIG. 1.- Hb level distribution in nursery school child population.

year, $12 \cdot 3 \mathrm{~g} / 100 \mathrm{ml}(\mathrm{SD} 1 \cdot 0)$ in the 4 th year, and $12 \cdot 4 \mathrm{~g} / 100 \mathrm{ml}(\mathrm{SD} 1 \cdot 0)$ in the 5 th year.

Seasonal variation. To examine the possibility of a seasonal variation in the absence of iron therapy, 585 children originally tested during the winter months were retested during the summer months. The initial $\mathrm{Hb}$ for this group of children is shown by the broken line in Fig. 2, with a mean of $12 \cdot 1$ $\mathrm{g} / 100 \mathrm{ml}$ (SD 1.0).

The repeat findings after the summer holidays on the same group of 585 children are shown by the firm line in Fig. 2, with a mean $\mathrm{Hb}$ of 12.3 $\mathrm{g} / 100 \mathrm{ml}(\mathrm{SD} 1 \cdot 0)$. This difference of $0.2 \mathrm{~g} / 100$ $\mathrm{ml}$ between the winter and summer mean $\mathrm{Hbs}$ is slight though statistically significant $(t=3 \cdot 42$, $P<0 \cdot 001)$.

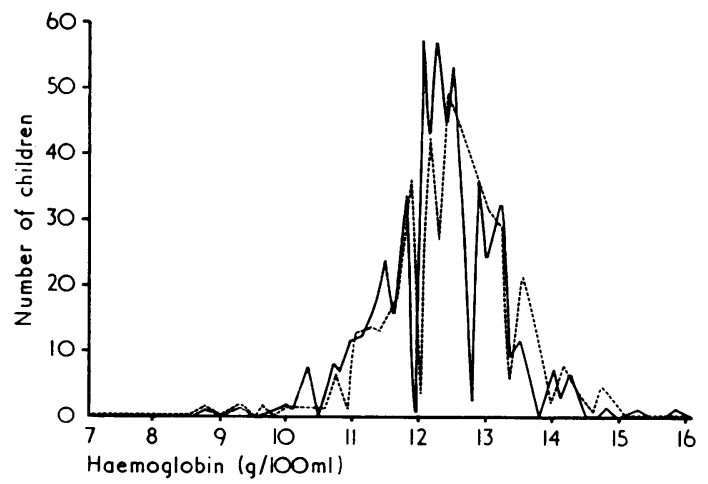

FIG. 2.-Seasonal comparison for the children at local authority nurseries. Hb distributions for winter (-- - ) and summer (-) are very similar.
Effect of iron administration. The $\mathrm{Hb}$ distribution for 163 children before iron administration is shown by the firm line (winter) and dashed line (summer) in Fig. 3. The mean $\mathrm{Hb}$ for this group immediately before iron administration was $11 \cdot 7$ g/100 ml (SD 0.8).

After 6 weeks of iron administration the mean $\mathrm{Hb}$ level was $12.5 \mathrm{~g} / 100 \mathrm{ml}$ (SD 0.8 ) and the distribution is shown by the dotted line in Fig. 3.

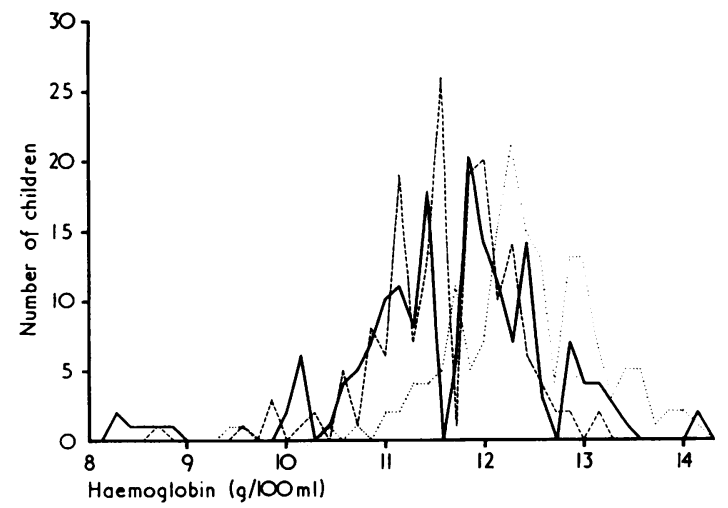

Frg. 3.-Hb distribution before iron therapy in winter $(\longrightarrow)$ and summer --- ), and after iron therapy in early autumn (....) for a group of 163 children. The minimal seasonal change provides a control for response to iron therapy.

There was thus a rise in the mean $\mathrm{Hb}$ level of $1 \mathrm{~g} / 100 \mathrm{ml}$ after iron administration in this group of children. The control study for this same group of 163 children without iron revealed a slight fall in the mean $\mathrm{Hb}$ level of $0.15 \mathrm{~g} / 100 \mathrm{ml}$ between winter and summer tests. The $\mathrm{Hb}$ rise after iron administration is statistically highly significant $(\mathrm{t}=9.0, \mathrm{P}<0.001)$ and its haematological significance becomes even clearer when it is related to the initial $\mathrm{Hb}$ level.

Relation of $\mathrm{Hb}$ change to initial $\mathrm{Hb}$ level. Table I provides a comparison of the mean $\mathrm{Hb}$ change

TABLE I

Mean Hb Changes Related to Initial Hb Level

\begin{tabular}{c|c|c}
\hline $\begin{array}{c}\text { Initial Hb } \\
(\mathrm{g} / 100 \mathrm{ml})\end{array}$ & $\begin{array}{c}\text { Winter to } \\
\text { Summer } \\
(\mathrm{g} / 100 \mathrm{ml})\end{array}$ & $\begin{array}{c}\text { Pre-iron to } \\
\text { Post-iron } \\
(\mathrm{g} / 100 \mathrm{ml})\end{array}$ \\
\hline$<10$ & $+0.7(10)$ & $+2.2(4)$ \\
$10 \cdot 1-10.8$ & $+0.6(15)$ & $+1.4(15)$ \\
$10.9-11.5$ & $+0.4(47)$ & $+0.8(58)$ \\
$11.6-12.3$ & $-0.1(56)$ & $+0.6(70)$ \\
$>12.4$ & $-0.9(35)$ & $-0.0(16)$ \\
\hline
\end{tabular}

Note: Figures in brackets indicate numbers of children in each relevant group. 
occurring spontaneously from winter to summer with that obtained after iron administration, related to the different initial $\mathrm{Hb}$ levels.

It can be seen that after iron administration the greatest mean $\mathrm{Hb}$ rise of $2 \cdot 2 \mathrm{~g} / 100 \mathrm{ml}$ occurred when the initial $\mathrm{Hb}$ was less than $10 \mathrm{~g} / 100 \mathrm{ml}$. Where the initial $\mathrm{Hb}$ was at this level but no iron was given, the spontaneous rise from winter to summer was one-third of that obtained after iron administration.

It is of note that if the initial $\mathrm{Hb}$ exceeded $12 \cdot 4$ $\mathrm{g} / 100 \mathrm{ml}$ no change in the mean $\mathrm{Hb}$ followed iron administration, the number of cases in which a rise occurred being exactly offset by those in which there was a fall.

Red cell appearance. The initial (winter) blood film examinations of the group of 585 children revealed that though there was some correlation between the $\mathrm{Hb}$ level and the degree of hypochromia (graded visually as slight, moderate, or severe), there was a wide scatter of $\mathrm{Hb}$ levels for each observed grade of hypochromia.

Relation of red cell appearance to iron therapy. Response to iron therapy was associated with a marked reduction in hypochromia. This is clearly shown in Fig. 4.

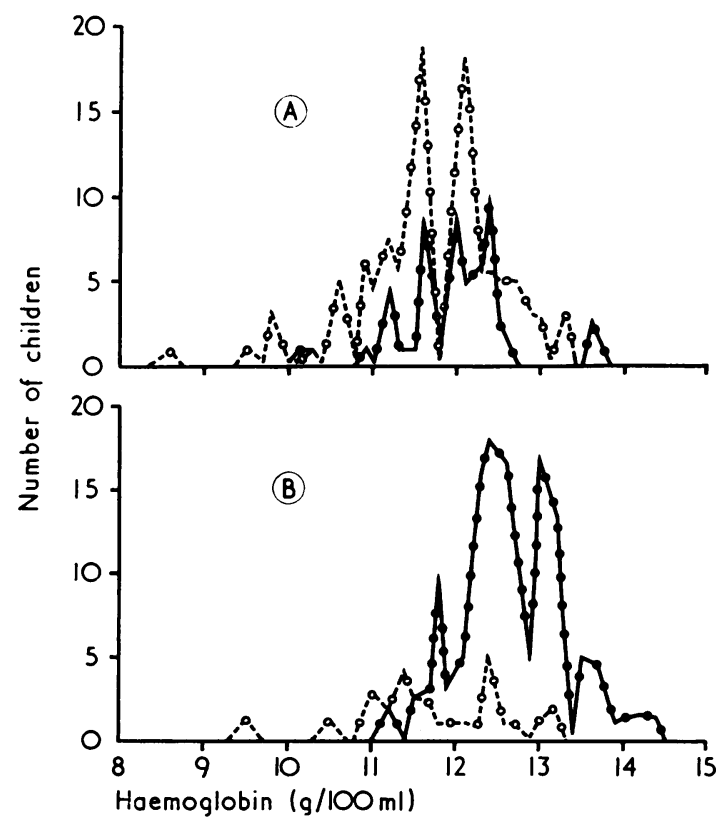

FIG. 4.-Relation of film appearance to iron therapy. Children with normochromia (O-O) and hypochromia $O-O),(A)$ before and $(B)$ after iron administration.
The great increase in the proportion of cases with normochromia and the corresponding reduction in the number of cases with hypochromia can be readily seen.

Social status and $H b$. The distribution pattern of the $\mathrm{Hb}$ for the 3 different social groups composing the sample of 1074 children is shown in Fig. 5.

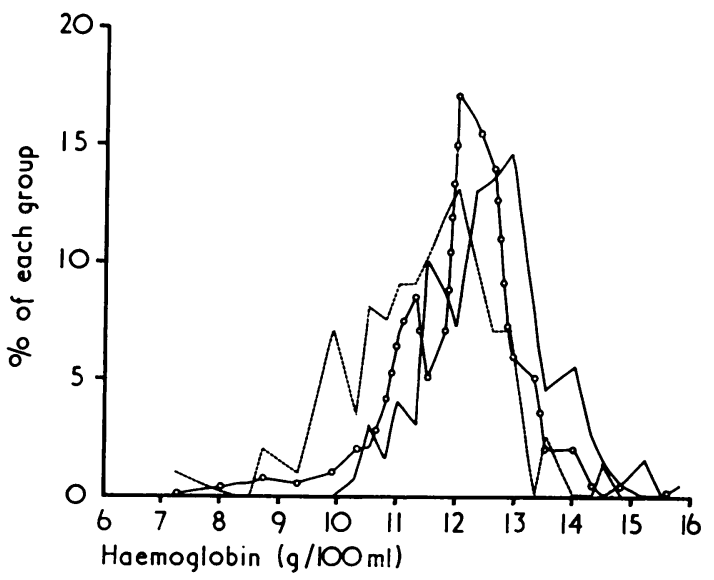

Fig. 5.-Comparison of $\mathrm{Hb}$ level distribution of children in private nurseries (-), local authority day nurseries $(\mathrm{O}-\mathrm{O})$, and on admission into care at the residential nurseries of the children's department (-- ). In the latter group there is a significantly higher proportion of infants with a low $\mathrm{Hb}$.

The mean $\mathrm{Hb}$ for each of these groups was: private nurseries $12.6 \mathrm{~g} / 100 \mathrm{ml}$ (SD 1); local authority nurseries $12 \cdot 2 \mathrm{~g} / 100 \mathrm{ml}$ (SD 1); and residential nurseries on admission into care $11 \cdot 4$ g/100 ml (SD 1.2).

The percentage of cases having $\mathrm{Hb}$ levels below $10.5 \mathrm{~g} / 100 \mathrm{ml}$ and above $13 \mathrm{~g} / 100 \mathrm{ml}$ for each group is shown in Table II.

\section{TABLE II}

Comparison of Percentage of Children in 3 Different Social Groups with $\mathrm{Hb}$ Levels Below $10.5 \mathrm{~g} / 100 \mathrm{ml}$ and $13.0 \mathrm{~g} / 100 \mathrm{ml}$

\begin{tabular}{c|c|c|c}
\hline $\begin{array}{c}\mathrm{Hb} \\
(\mathrm{g} / 100 \mathrm{ml})\end{array}$ & $\begin{array}{c}\text { \% of } \\
\text { Children at } \\
\text { Private } \\
\text { Nurseries }\end{array}$ & $\begin{array}{c}\% \text { of } \\
\text { Children at } \\
\text { Day } \\
\text { Nurseries }\end{array}$ & $\begin{array}{c}\% \text { of } \\
\text { Children on } \\
\text { Admission } \\
\text { into Care }\end{array}$ \\
\hline$<10.5$ & $\begin{array}{c}3.3 \\
>13.0\end{array}$ & $\begin{array}{c}3.7 \\
8.8\end{array}$ & $\begin{array}{r}15.0 \\
1.5\end{array}$ \\
\hline
\end{tabular}


If the lower limit of the normal is taken as 2 SDs below the mean level then the following figures are obtained as the lower 'normal' limit for each group, private nurseries $10.8 \mathrm{~g} / 100 \mathrm{ml}$, local authority nurseries $10.3 \mathrm{~g} / 100 \mathrm{ml}$, and on admission into care $9 \cdot 4 \mathrm{~g} / 100 \mathrm{ml}$.

Since a proportion of the children admitted into care were known to be deprived children, the figures obtained for this group may be discarded as abnormal. The other two figures are quite close together and the figure of $10.5 \mathrm{~g} / 100 \mathrm{ml}$ may reasonably be defined as the figure below which anaemia is deemed to exist. Of the 1074 children studied, $5 \cdot 2 \%$ were below this figure.

\section{Discussion}

A striking finding was the very wide $\mathrm{Hb}$ range found in apparently normal children, extending from 6.8 to $15.6 \mathrm{~g} / 100 \mathrm{ml}$. Excluding the cases at the two extremes there was a near normal distribution curve pattern between the levels of $8 \cdot 4$ and $15 \cdot 2 \mathrm{~g} / 100 \mathrm{ml}$. To a clinical observer this wide variation in $\mathrm{Hb}$ level was not readily apparent. Even the children with a $\mathrm{Hb}$ below $10.5 \mathrm{~g} / 100 \mathrm{ml}$ did not appear appreciably paler than their fellows. Often the pale child was found to have a high $\mathrm{Hb}$ level.

The mean $\mathrm{Hb}$ level for the whole group of 1074 children was $12 \cdot 3 \mathrm{~g} / 100 \mathrm{ml}$. Sex differences were minimal and seasonal variation was slight. The upward trend in the $\mathrm{Hb}$ level with increasing age was considerably less in the present study than that found by workers in a number of other countries (Table III).

It can be seen that several of these studies reveal a considerable rise in the $\mathrm{Hb}$ level with increasing age. In New Zealand, for example, the Maoris showed a $\mathrm{Hb}$ rise of $2.5 \mathrm{~g} / 100 \mathrm{ml}$ between the ages of 2 and 5 years, compared with only $0.4 \mathrm{~g} / 100 \mathrm{ml}$ for Cardiff. The low $\mathrm{Hb}$ level of Maori children at 2 years was probably due to prolonged breast feeding and consequent delay in obtaining a balanced diet. The very low figures for Bombay children were the result of grossly inadequate iron intake throughout childhood (Currimbhoy and Phadke, 1963).

In order to study the effect of iron administration it was essential to have adequate supervision to ensure that each child did take one iron tablet each day. The response obtained, particularly the mean rise of $2.2 \mathrm{~g} / 100 \mathrm{ml}$ when the initial $\mathrm{Hb}$ level was $10.5 \mathrm{~g} / 100 \mathrm{ml}$ or less, was both statistically and haematologically significant.

Of the children at private nurseries only $0.3 \%$ were found to have a $\mathrm{Hb}$ level of less than 10.5
TABLE III

Mean $\mathrm{Hb}$ Levels $(\mathrm{g} / 100 \mathrm{ml})$

\begin{tabular}{|c|c|c|c|}
\hline Country & At 2 Years & At 5 Years & Authors \\
\hline $\begin{array}{l}\text { South Africa } \\
\text { Whites } \\
\text { Cape Coloured } \\
\text { Africans }\end{array}$ & $\begin{array}{l}11 \cdot 6 \\
10 \cdot 1 \\
10 \cdot 6\end{array}$ & $\begin{array}{l}12 \cdot 2 \\
11 \cdot 0 \\
11 \cdot 1\end{array}$ & $\begin{array}{l}\text { Lanzkowsky and } \\
\text { McKenzie (1959) }\end{array}$ \\
\hline $\begin{array}{l}\text { New Zealand } \\
\text { Europeans } \\
\text { Maoris }\end{array}$ & $\begin{array}{r}11 \cdot 9 \\
9 \cdot 9\end{array}$ & $\begin{array}{l}12 \cdot 6 \\
12 \cdot 4\end{array}$ & Akel et al. (1963) \\
\hline $\begin{array}{l}\text { India } \\
\text { Bombay }\end{array}$ & $7 \cdot 6$ & $8 \cdot 8$ & $\begin{array}{l}\text { Currimbhoy and } \\
\text { Phadke (1963) }\end{array}$ \\
\hline $\begin{array}{l}\text { Australia } \\
\text { Queensland }\end{array}$ & $12 \cdot 4$ & $13 \cdot 9$ & McFarlane (1964) \\
\hline$U S A$ & $\begin{array}{l}11 \cdot 5 \\
13 \cdot 0\end{array}$ & $\begin{array}{l}12 \cdot 6 \\
13 \cdot 5\end{array}$ & $\begin{array}{l}\text { Wintrobe (1967) } \\
\text { Silver, Kempe, and } \\
\text { Bruyn (1969) }\end{array}$ \\
\hline $\begin{array}{l}\text { Negroes of } \\
\text { Washington, } \\
\text { D.C. }\end{array}$ & $10 \cdot 5$ & $11 \cdot 2$ & Gutelius (1969) \\
\hline $\begin{array}{l}\text { Britain } \\
\quad \text { Cardiff }\end{array}$ & $12 \cdot 0$ & $12 \cdot 4$ & Present study \\
\hline
\end{tabular}

$\mathrm{g} / 100 \mathrm{ml}$. The proportion of correspondingly anaemic children in local authority day nurseries was $3 \cdot 7 \%$, i.e. 12 times greater, and of children taken into care at the two residential nurseries was $15 \%$, i.e. 50 times greater than at private nurseries.

A practical outcome of these findings is that children taken into care in Cardiff are being given iron tablets as a routine on admission. The incidence of anaemia in the local authority day nurseries might also be considered sufficient to justify appropriate action being taken. The administratative problems are forbidding; but it is remarkable how readily the infants themselves co-operate away from an atmosphere of parental apprehension of fingerpricks, in sharp contrast to those children attending hospital outpatients with their parents. A simple screening method undertaken at the nurseries, such as the copper sulphate densitometric test used by blood donor attendants and also found to be a manageable procedure for children (Costeff, 1965), might well be a practical proposition to eliminate the $95 \%$ or so who do not require either further examination or iron therapy.

We wish to acknowledge the co-operation extended to us by Mr. J. B. Williams, City Children's Officer, Dr. D. J. Anderson, M.O.H. and Principal School Medical Officer, Mrs. Janet L. Brown of the Medical Illustration Department, Mr. M. Page of the Welsh Hospital Board Computer Centre, the Staff of the nurseries and schools in Cardiff, the parents, and the children themselves. 


\section{REFERENCES}

Akel, R. N., Frankish, J. D., Powles, C. P., Tyler, K. R., Watt, J. M., Weston, H. J., and Prior, I. A. M. (1963). Anaemia in Maori and European infants and children on admission to hospital: a co-operative survey from six New Zealand hospitals. New Zealand Medical fournal, 62, 29.

Costeff, H. (1965). Methods of routine haemoglobinometry in childhood; evaluation of copper sulphate densitometry. Archives of Disease in Childhood, 40, 309.

Currimbhoy, Z., and Phadke, P. (1963). Survey of anemia in children of Bombay. Indian fournal of Child Health, 12, 469.

Gutelius, M. F. (1969). The problem of iron deficiency anemia in preschool negro children. American fournal of Public Health, 59, 290.
Lanzkowsky, P., and McKenzie, D. (1959). Iron deficiency anaemia in Cape coloured, and African children in Cape Town. South African Medical Fournal, 33, 21.

McFarlane, J. (1964). Haemoglobin levels in babies and young children. Medical fournal of Australia, 2, 364.

Silver, H. K., Kempe, C. H., and Bruyn, H. B. (1969). Handbook of Pediatrics, 8th ed., p. 631. Lange, Los Allios, California; Blackwell, Oxford.

Wintrobe, M. M. (1967). Clinical Hematology, 6th ed., p. 86. Lea and Febiger, Philadelphia; Kimpton, London.

Correspondence to Dr. D. M. D. Evans, Department of Pathology, Group Laboratory, St. David's Hospital, Cowbridge Road, Cardiff CF1 9TZ.

The following articles will appear in future issues of this journal:

Review Article: Dental Caries. By W. H. Bowen.

Spina Bifida Cystica: Results of Treatment of 270 Consecutive Cases with Criteria for Selection for the Future. By J. Lorber.

Congenital Hypothyroidism: Aetiological and Clinical Aspects. By J. Mäenpää.

Annotation: Breast Milk and Defence Against Infection in the Newborn. By L. A. Hanson and J. Winberg.

Asthma-The Physiological and Clinical Spectrum in Childhood: Respiratory Function Studies in Its Assessment. By D. J. Hill, L. I. Landau, K. N. McNicol, and P. D. Phelan.

Neonatometer: A New Infant Length Measurer. By D. P. Davies and R. E. Holding.

Chronic Chest Disease in Australian Aboriginal Children. By G. M. Maxwell.

Personal Practice: Congenital Anomalies of the Anus and Rectum. By A. W. Wilkinson.

Malignant Nonchromaffin Paraganglioma. By P. DeBuse.

Accidental Poisoning with Thyroid Extract Treated by Exchange Transfusion. By P. Gerard, P. Malvaux, and M. DeVisscher.

Bacterial Infection in Cystic Fibrosis. By J. R. May, N. C. Herrick, and D. Thompson.

Birthweight Distribution in Congenital Pyloric Stenosis. By A. Czeizel.

Septo-optic Dysplasia with Growth Hormone Deficiency (DeMorsier Syndrome). By R. J. Harris and L. Haas. 